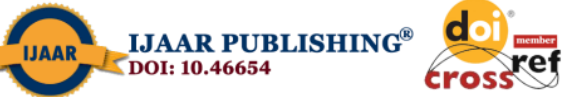

International Journal of Advanced Academic Research (Sciences, Technology and Engineering) | ISSN: 2488-9849 Vol. 7, Issue 2 (February, 2021) |www.ijaar.org

Journal DOI: www.doi.org/10.46654/ij.24889849

Article DOI: www.doi.org/10.46654/ij.24889849.e7211

\title{
CO-DIGESTION OF KITCHEN WASTE WITH INTESTINAL COW DUNG FOR BIOGAS PRODUCTION
}

\author{
Udensi, J. $\mathrm{U}^{1}$, Ejiogu, C. C ${ }^{2}$, Okafor, H. $\mathrm{O}^{3}$, Uyo, C. $\mathrm{N}^{2}$, Iwuji, K. $\mathrm{M}^{2}$, Esomonu $\mathrm{I}^{2}$ and \\ Akueshi, C. $\mathrm{U}^{4}$ \\ ${ }^{1}$ Department of Environmental Health Federal University of Technology, P.M.B 1526, Owerri. \\ Nigeria \\ ${ }^{2}$ Department of Environmental Management Federal University of Technology, P.M.B 1526, \\ Owerri. Nigeria \\ ${ }^{3}$ Department of Biotechnology Federal University of Technology, P.M.B 1526, Owerri. Nigeria \\ ${ }^{4}$ Department of Environmental Biology, Federal Polytechnic Nekede, P.M.B 1036, Owerri, \\ Nigeria \\ Corresponding email-uyochijioke@yahoo.com
}

\begin{abstract}
Anaerobic digestion process is gaining attention in the agriculture industry because of its potential for renewable energy production and manure stabilization. These potential benefits are significant against the current backdrop of rising energy costs and growing environmental concerns. Anaerobic digestion is a naturally occurring process through which organic matter such as manure, feed spills, meat processing wastes and crop residues are stabilized by microorganisms strictly in the absence of air. In developing countries, the inadequate management of waste particularly in urban areas where the consumption pattern have changed and the generation rate increased substantially from one location to another and from time to time. This study explored the production of biogas from kitchen wastes mixed with intestinal cow dung in a semi continuous anaerobic digester. Materials used as feed were Paw Paw, tomato, banana peels and intestinal cow dung. Various parameters were determined using standard methods; water displacement method was used to determine the volume of gas produced. The combustibility of the gas generated was tested using Bunsen burner. Microbiological methods were employed for the microbiological analysis. The temperature and $p H$ recorded in the digester range from $27-33^{\circ} \mathrm{C}$ and $0-6.81 \mathrm{c}$ respectively. It was observed that the waste slurry produced biogas without nutrient or chemical addition to the digester. The highest volume of gas $(2.8 \mathrm{ml})$ was produced on the $14^{\text {th }}$ day where the temperature $\left(29^{\circ} \mathrm{C}\right)$ and $\mathrm{pH}$ (6.79) were relatively high. The result of the statistical analysis showed there is significant difference $(P<0.05)$ in the slurry temperature and $\mathrm{pH}$ as compared to the volume of gas produced. The Bacteria isolates identified from the digester include Proteus Spp, Bacillus Spp, Escherichia Coli, Klebsiella Spp and Staphyllococcus Spp. Based on this, the search for alternative source of Energy such as Biogas should be intensified so as to curb the incidence of ecological disasters like Environmental pollution, deforestation, desertification and erosion.
\end{abstract}

Keywords: Co-digestion, Waste, Biogas Production. 


\section{Introduction}

Energy production from fossil fuels becomes more and more problematic since these resources are running short and burning of coal, oil and natural gas is connected with emission of the green house gas Carbon dioxide. It is intended to enhance the proportion of biomass for energy production. Long-term objectives of this policy are to ensure energy supply and to reduce green-house emissions. Biogas production from renewable resources or organic wastes is of importance (1). Biogas consists of methane, Carbon dioxide and low amounts of other gases. It is produced during anaerobic fermentation of organic substrates by specific microbial communities (8). This process is biotechnologically exploited to produce Biogas in commercial biogas plants (3).

Anaerobic digestion is becoming more and more attractive for the treatment of high strength organic wastes such as municipal solid wastes since it produces renewable energy, methane and valuable digested residues, liquid fertilizer and soil conditioner(2)

Fruits and vegetables wastes are produced in large quantities in markets, and contribute a source of nuisance in municipal landfills because of their high biodegradability (11). These local manure which could either be from animal herds, agricultural or industrial waste that are largely produced in Nigeria on a daily basis could be employed as raw material for both small and large scale biogas production. The amount of fresh waste generated in Nigeria is around 227,500 ton/day, and contains more than $70 \%$ of organic wastes; the easy biodegradable organic matter content of vegetables waste with high moisture content facilitates their biological treatment and shows the trend of these wastes for anaerobic digestion (4). Biogas technologies commonly apply natural anaerobic consortia of microbes.

The use of biomass is one of the most promising technological generations, however its main constituents are methane and different percentages can be obtained by using various raw materials. Biogas from organic waste digesters usually contains from 60-70\% methane, 30-40\% carbon dioxide, and $<1 \%$ nitrogen. Biogas from sewage digesters usually contains from 53-65\% methane, $35-45 \%$ carbon dioxide, $<1 \%$ nitrogen and hydrogen sulphide.

Anaerobic digestion of animal wastes could have a huge impact on renewable energy requirements. It is best suited to convert organic wastes from agriculture, livestock, industries, municipalities and other human activities into energy and fertilizers. Owing to the important roles demonstrated by rumen microorganisms in anaerobic digestion (10), animal manures have been established as suitable sources of Biogas production in Africa, although they are codigested with energy crops (6). Co-digestion refers to the simultaneous anaerobic digestion of multiple organic wastes in one digester. This principle enhances methane yield due to positive interactions established in the digestion medium, bacterial diversities in different wastes and the supply of missing nutrients by the co-substrate (7).

Overall, anaerobic digestion reduces biomass waste and mitigates a wide spectrum of environmental undesirables; it improves sanitation, helps in air and water pollution control and reduces greenhouse gas emission. Also, it provides a high-quality nutrient-rich fertilizer and yield energy in the form of Biogas. The uses of Biogas vary greatly from developing to developed countries. In Africa, Biogas generated can be used as fuel for cooking, lighting and heating, it reduces the demand for wood and charcoal for cooking therefore helps preserve forested areas and natural vegetation, and can help alleviate very serious health problem due to poor indoor air quality associated with wood and charcoal used for cooking(5) 


\section{Materials and Methods}

Reagents used were obtained from the biotechnology Laboratory, Federal University of Technology, Owerri. These include Kovac's reagent, simon citrate Augar, hydrogen peroxide, TSI agar, sterile peptone water, distilled water, nutrient agar, crystal violet, gram's iodine, ethyl alcohol, safranin and tetramethyl-p-phynylene-diamine dihydrochorid.

Apparatus used include manual Biodigester of 10 litre capacity, petri dishes, electrical weighing balance, spatula, desicator, mercury in glass thermometer $\left(0-100^{\circ} \mathrm{C}\right), \mathrm{pH}$ meter, gas burner, incubator stand, beakers, conical flasks, syringes, measuring cylinder(pyrex), crucible, buchner funnel, oven, hose pipe, water trough, graduated (transparent bucket), evaporating(porcelain) dish, desicators, glass slides, inoculating loop, micropipettes, test tubes, Autoclave, test tube racks, Bunsen burner, separating funnel, bibulous paper, microscope, lens paper and cleaner, immersion oil, autoclave. Others include plastic barrels, PVC pipes $(63 \mathrm{~mm}), 2$ bushings $(63 \mathrm{~mm})$, Air valve $(63 \mathrm{~mm})$, Gas locks and 1/2" socket, PVC Hoses, ABRO PVC gum, 4 minutes gum9 (Hardner and Resin), Threaded tape, Tire tubes, Galvanized pipe $(63 \mathrm{~mm})$, Galvanized pipe (1/2”), wrench, Hack saw, knife.

\section{Collection and processing of samples}

Fresh cow dung was collected from the Obinze Abattoir in Owerri West Local Government Area of Imo State of Nigeria.

Varied quantity of food waste (Mango, Banana peel, Avocado, Papaya, and Tomato) and intestinal cow dung waste were weighed out and thoroughly mixed in a calibrated plastic bowl before charging into 10 litres bioreactor. Appropriate quantities of water 2:1 ratio to the waste were used. The quantity varies with the moisture content of the waste used.

\section{Experimental design}

Semi continuous bioreactor of 10 liter capacity was charged up to $3 / 4$ of the bioreactor volume, varying the amount of Cow dung and kitchen waste while the volume of water remained constant.

The anaerobic biogas generation from kitchen wastes mixed with Cow manure was attempted using a smaller (10L) plastic container with dimensions of diameter $24 \mathrm{~cm}$ on each end a height of $30 \mathrm{~cm}$. The digester had two openings, one of these, $5 \mathrm{~cm}$ in diameter, was connected to a gas collector of inverted smaller transparent bucket in a bigger one, through the base was connected to the Bunsen burner through a rubber tube and served as outlet for the gas generated. The first opening is left uncovered for subsequent feeding of the digester with slurry at the gas depreciating stage, while the other was made air tight throughout the digestion process.

\section{Analysis of waste}

Several analyses were carried out on the waste samples and these include microbiological analysis on the slurry and physicochemical analysis of the individual waste sample.

\section{Microbiological analysis}

Samples for microbial analysis were collected immediately the digester was set up in a collection bottle. The analysis was carried out to determine and estimate the microbial population present in anaerobic digestion and to identify the specific organism's present. The 
media was prepared according to the Manufacturers specification and the media used were: Nutrient agar (NA), Eosine methylene blue agar (EMBA). The samples (slurry and distilled water) were serially diluted by carrying out a 10 -fold serial dilution after which $0.1 \mathrm{ml}$ of sample was inoculated into the already prepared media in the petri dish by spread plate method. After inoculation, the plates were incubated for $24-48$ hours at $37^{\circ} \mathrm{C}$ for NA, and EMBA. After inoculation, the colonies formed were counted and were expressed as colony forming units per gram $(\mathrm{CFU} / \mathrm{g})$ to obtain total population.

\section{Characterization of microbial isolates}

The microbial isolates were characterized using staining, catalase, coagulate, indole, methyl Red and voges-proskaeur, citrate utilization, oxidase, urease, proximate tests analysis.

Moisture content, ash content, total solid and volatile solids were measured using standard methods.

\section{Result}

TABLE 1: TOTAL BACTERIA COUNT FROM KITCHEN WASTE AND INTESTINAL COW DUNG BEFORE BIOGAS PRODUCTION

\begin{tabular}{|c|c|c|c|c|c|c|}
\hline Sample & Media & Colour & Size & Shape & Elevation & $\begin{array}{l}\text { Total } \\
\text { count }(\mathrm{cfu} / \mathrm{ml})\end{array}$ \\
\hline \multirow{2}{*}{$\begin{array}{l}\text { Kitchen } \\
\text { waste + } \\
\text { intestinal } \\
\text { cow } \\
\text { dung }\end{array}$} & NA & Creamy & $1-3$ & Irregular & Flat & $5.3 \times 10^{6}$ \\
\hline & EMB & $\begin{array}{l}\text { Green } \\
\text { metallic } \\
\text { sheen } \\
\text { and } \\
\text { violet }\end{array}$ & $1-3$ & Irregular & Raised & $5.0 \times 10^{4}$ \\
\hline
\end{tabular}




\section{TABLE 2: BIOCHEMICAL IDENTIFICATION OF SOME BACTERIA ISOLATED FROM KITCHEN WASTES AND COW DUNG AFTER BIOGAS PRODUCTION}

\begin{tabular}{|l|l|l|l|l|l|l|l|l|l|}
\hline $\begin{array}{l}\text { SN } \\
\text { Colour }\end{array}$ & $\begin{array}{l}\text { Gram } \\
\text { reaction }\end{array}$ & Catalase & Glucose & Sucrose & Motility & Indole & Lactose & Citrate & $\begin{array}{l}\text { Bacteria } \\
\text { isolated }\end{array}$ \\
\hline $\begin{array}{l}\text { Swoby } \\
\text { Colony }\end{array}$ & -- & -- & + & + & + & + & -- & + & Proteus spp \\
\hline $\begin{array}{l}\text { Creamy } \\
\text { Rhyzolike }\end{array}$ & + & + & + & + & -- & -- & -- & + & Bacillus spp \\
\hline $\begin{array}{l}\text { Erase } \\
\text { Colony }\end{array}$ & -- & + & + & + & -- & -- & -- & + & $\begin{array}{l}\text { Entherobacter } \\
\text { spp }\end{array}$ \\
\hline Milkish & + & + & + & + & -- & -- & -- & + & Bacillus spp \\
\hline $\begin{array}{l}\text { Whitish } \\
\text { Roundy }\end{array}$ & -- & + & + & + & + & + & -- & + & E.coli spp \\
\hline $\begin{array}{l}\text { Creamy } \\
\text { Mucoid }\end{array}$ & -- & + & + & -- & + & -- & -- & + & Klebsiella spp \\
\hline $\begin{array}{l}\text { Tiny } \\
\text { white }\end{array}$ & + & + & -- & -- & -- & -- & -- & + & $\begin{array}{l}\text { Staphyllococcus } \\
\text { spp }\end{array}$ \\
\hline $\begin{array}{l}\text { Large } \\
\text { Colony }\end{array}$ & + & + & -- & -- & -- & -- & -- & + & Bacillus spp \\
\hline
\end{tabular}

KEY: $+=$ Positive

--=Negative

\section{Ambient Temperature, Slurry temperature, pH, and Cumulative Biogas volume Yield}

The anaerobic digestion of cow dung generated some volume of biogas over the four-week digestion period. There was biogas production in the first two days of anaerobic digestion. The biogas yield of $2.8 \mathrm{ml}$ was observed in the $14^{\text {th }}$ day while the least was observed in the $22^{\text {nd }}$ day. The biogas yield decreases as the day increased 
Table 3: AMBIENT TEMPERATURE, SLURRY TEMPERATURE, PH, AND VOLUME OF BIOGAS PRODUCED.

\begin{tabular}{|c|c|c|c|c|c|}
\hline Days & Ambient temperature & $\begin{array}{l}\text { Slurry temperature } \\
\qquad\left({ }^{0} \mathrm{c}\right)\end{array}$ & $\mathrm{pH}$ & Volume(ml) & Combustion \\
\hline 1 & 32 & 29 & 6.56 & 1.2 & $\mathrm{No}$ \\
\hline 2 & 30 & 28.5 & 6.68 & 1.6 & No \\
\hline 3 & 31 & 28 & 6.70 & 1.4 & No \\
\hline 4 & 28 & 29 & 6.10 & 1.5 & $\mathrm{No}$ \\
\hline 5 & 30 & 27.5 & 6.00 & 1.5 & No \\
\hline 6 & 32 & 30 & 6.20 & 1.7 & No \\
\hline 7 & 29 & 29 & 6.40 & 1.8 & No \\
\hline 8 & 31 & 28 & 6.60 & 1.5 & No \\
\hline 9 & 32 & 29 & 6.50 & 1.7 & No \\
\hline 10 & 30 & 28.5 & 6.70 & 2.3 & Yes \\
\hline 11 & 29 & 28 & 6.60 & 2.2 & Yes \\
\hline 12 & 28.5 & 27 & 6.50 & 2.2 & Yes \\
\hline 13 & 29 & 30 & 6.40 & 2.5 & Yes \\
\hline 14 & 30 & 29 & 6.79 & 2.8 & Yes \\
\hline 15 & 31 & 30 & 6.65 & 2.4 & Yes \\
\hline 16 & 27.5 & 29 & 6.75 & 2.3 & Yes \\
\hline 17 & 31 & 28 & 6.50 & 2.3 & Yes \\
\hline 18 & 32 & 31 & 6.65 & 2.1 & Yes \\
\hline 19 & 31.5 & 30 & 6.67 & 2.4 & Yes \\
\hline 20 & 29.5 & 29.5 & 6.78 & 2.3 & Yes \\
\hline 21 & 31 & 28.5 & 6.65 & 2.2 & Yes \\
\hline 22 & 32 & 29 & 6.76 & 2.1 & Yes \\
\hline 23 & 33 & 28 & 6.56 & 2.4 & Yes \\
\hline 24 & 29 & 33 & 6.73 & 2.1 & Yes \\
\hline 25 & 28 & 31 & 6.81 & 2.3 & Yes \\
\hline 26 & 30 & 32 & 6.79 & 2.2 & Yes \\
\hline 27 & 32 & 30 & 6.82 & 1.9 & Yes \\
\hline 28 & 30 & 29.5 & 6.78 & 1.8 & Yes \\
\hline 29 & 31 & 31 & 6.69 & 1.2 & Yes \\
\hline 30 & 32 & 33 & 6.81 & 1.6 & Yes \\
\hline
\end{tabular}

\section{Discussion and Recommendation}

The results demonstrate that biogas yields after 30 days digestion time are influenced by the mixing ratio, the equal the ratio, the higher the biogas yield. This positive relation might be due to high methanogenetic activity and/or the number of methanogens in the digester, that could result in the fewer amount of volatile fatty acids (VFA) produced during the acidogenic phase. Nevertheless, the final average $\mathrm{pH}$ values measured for the studied reactors were at least 6.82 . The production of flammable biogas commenced 78 hours of charging. The high production of biogas observed in bioreactor (1:2) could be attributed to the high waster ratio in the slurry. The result from the study showed that Bacillus species were the most common bacteria isolated and identified during the research, suggesting that the species plays a role in the production of 
biogas. The Bacillus species to overlap during the production were probably due to the fact that the organisms can produce spore which help to withstand the harsh anaerobic condition or heat evolved during the biogas production. In line with (8) in which Bacillus and Pseudomonas species were found to be responsible for biogas production from kitchen waste and cow dung. The result from triple sugar ion (Glucose, Sucrose, and Lactose) shows that some of the organisms found in the cow dung utilizes Glucose and Sucrose more in bioreactor, no organism utilized lactose. In tandem with the report of (11) reported slow biogas production at starting and end of study period which was predicted because biogas production rate in batch condition is directly equal to specific growth of methanogenic bacteria.

The cultural morphology and gram reaction revealed colonies with creamy irregular edge and with different gram reaction. Multiplication of bacteria was slow initially and gradually increased in the second week. Growth entered in the third week and highest growth was recorded in the bioreactor.

\section{Recommendation}

This study has shown that intestinal cow dung and kitchen waste can be used to produce biogas which could be used to address the socio economic and environmental problems facing the country. The mathematical modeling further studies the determination of other agents (such as maintaining of mesophilic temperature and $\mathrm{pH}$ range, additives that enhance the production of biogas) for anaerobic digestion. With the creation of the World Biogas Association (WBA) that aim to zero the emission of green house gas and mitigate many of the impacts of climate change through capturing organic wastes, producing renewable energy and returning nutrients and organic content to the soil.

\section{Acknowledgement}

The authors are grateful to our field assistants and laboratory Scientists for their doggedness in helping to organize the practical materials for this paper. 


\section{References}

[1] Abubakar, B.S.U. and Nasir, I. (2012). Anaerobic digestion of cow dung for biogas production. Applied Science. 7(2): 69-70

[2] Angelidaki, I. and Ahring, B. K., (1994) anaerobic thermophilic digestion of manure at different ammonia loads, water research. 28(3): 727-731.

[3] Angelidaki, I., Ellegaard, L., and Ahring, B. K., (2003) Application of anaerobic process. Advance Biochemistry Eng. Biotechnology. 83:1-33.

[4] Bouallagui, H., Ben Cheikh., Marouani, I., and Hamdi, M., (2003) mesopholic biogas production from fruit and vegetable waste in a tabular digeste, bioresource technology, 86:8589.

[5] Brown, V. J., (2006). Biogas bright idea for Africa. Environmental Health Perspective Ves journal, 114:301-303.

[6] Kalakeshev, D., Batstone, D. J., Trably, E. and Angelidaki, I. (2006) Acetate oxidation is the dominant methanogenic pathway from acetate in the absence of methanogaetacease, Applied Environmental Microbiology, 72:5138-5141.

[7] Li, L., Jin, T., Sommers, C.H., Boyd, G., and Zhang, H. (2009) Radiation sensitization and postirradiation proliferation of listeria monocytogene on ready to eat deli meat in the presence of pectin. Nsinfilms. Journal of food protection. 72:644-649.

[8] Ohmiya, K., Sakka, K. and Kimura, T., (2005) Anaerobic bacterial degradation for the effective utilization of biomass. Biotechnology bioprocess Eng., 10:482-493.

[9] Oluleya, I. O., Femi-Ola, T. O. and Opomu, D. (2006). Anaerobic digestion of cassava peels mixed with pig waste for Biogas and fertilizer production. Nigeria Journal of Microbiology. 3:2-7.

[10] Uzodinma, E. O and Ofoefule, A. U. (2009). Biogas production from blends of field grass (panicum maximum) with some Animal waste. International Journal of Physical science, 4(2):91-95.

[11] Viturta, A., Mata-Alvarez, J., Cecchi, F. and Fazzini, G., (1989) Two phase anaerobic digestion of a mixture of fruits and vegetable wastes, biological wastes 29:189-199.

[12] Weiland, P., (2003) Production and energetic use of biogas from energy crops and wastes in Germany. Application of biochemistry and biotechnology.109:263-274. 